\title{
Characteristics of Physical Loads of Young Footballers During a Championship Match
}

\author{
by \\ Marcin Andrzejewski ${ }^{1}$, Beata Pluta ${ }^{1}$, Dariusz Posiadała ${ }^{1}$
}

\begin{abstract}
The aim of the work was to characterize physical loads present during a champion match among young footballers. The research was conducted on a group of 10 football players at the age of $13.5 \pm 0.4$, with training experience of 4 years. The average body height of the players was $162.32 \pm 7.73 \mathrm{~cm}$ and the average body mass was $51.12 \pm 7.72$ $\mathrm{kg}$. In effort to analyze the selected motor performances of the players during the match, a kinematic method by Erdmann (2000) was applied. The analysis of motor activeness was conducted during the first and the second half of the game. The results are shown as arithmetic means and standard deviation. To compare the values, Student's t-test for the linked samples was applied. The significance level was $p \leq 0.05$. The results of the study show that the total distance covered by the young football players averaged 4,252 metres. The longest, statistically relevant mean distance $(p \leq 0.05)$ was covered by the midfielders $(4,486 \mathrm{~m})$. The analysis of the mean distance covered by the players with an established speed below the anaerobic threshold was 3,596 \pm 207 metres, which makes up $84.57 \%$ of the total distance covered during the game. A thorough analysis of the number of sprints revealed that a player performs 18 of them on average throughout the game. The highest maximum running speed $(7.0 \mathrm{~m} / \mathrm{s})$ was achieved by the midfielders. The defenders proved to be slowest $(6.5 \mathrm{~m} / \mathrm{s})$, while the forwards had the second fastest average maximum running speed $(6.8 \mathrm{~m} / \mathrm{s})$.
\end{abstract}

Key words: physical loads, motor performance, match distance covered, sprint

\section{Introduction}

Football is one of the most popular sport disciplines in the world, which can be played by men, women and children alike, regardless of their abilities. It is a very dynamic discipline with a growing number of direct encounters, which requires that players have excellent motor, technical, tactical and mental preparation (Reilly, 2007). Progressively more attention has been devoted toward selecting players with the right anthropometric and fitness profiles, which would enable a systematic training process, designed to achieve the highest sport level. Preparing a player often means improving their technical or tactical abilities, at the expense of shap- ing their motor abilities (Bangsbo, 1994; Reilly, 2003; Stølen et al., 2005).

The duration of a football match makes this discipline an aerobic sport, during which energy is mainly produced by means of aerobic metabolism. The average effort intensity, measured in percentage of the maximum heart rate (MHR) during a ninetyminute game, does exceed anaerobic threshold (Bangsbo et al., 1991; Rienzi et al., 2000; Strudwick Reilly, 2000; Stølen et al., 2005; Krustrup et al., 2005). The total distance covered during a game by footballers with the highest sport level often exceeds 12 kilometers, and even $4 \mathrm{~km}$ for goalkeepers (Bangsbo, 1999; Helgerud et al., 2001; Ohashi et al., 2002; Harley et al., 2002; Mohr et al., 2003; Castagna et al., 2003; Chmura et al., 2003; Chmura et al., 2004). The

1 - Faculty of Methodology and Recreation, University School of Physical Education, Poznan 
intensity of effort and the distance covered by players during the second half of the game is from $5 \%$ to $10 \%$ less when compared to the first half of the match. However, a cyclic and interspersed character of the game is responsible for the occurrence of short-term efforts made with the highest intensity, in which ATP resynthesis takes place by means of anaerobic metabolism (Mohr et al., 2003; Chmura et al., 2004). During championship matches, efforts of high intensity sprints take place on average every $90 \mathrm{sec}-$ onds and last from 2 to 4 seconds. Thus, sprints make up from 1 to $11 \%$ of the total distance covered by players during a game, which translates into 0.5 $3 \%$ of the effective game time (Valquer et al., 1998; Wisløff et al., 2004; Spencer et al., 2005). Despite the enduring character of the game, players perform many, usually short in length, motor activities changing every 4 - 6 seconds, which consist of (among others): about $10-20$ sprints, high-intensity running taking place about every 70 seconds, approximately 15 halts, 10 headers and 50 other activities concerning ball-control (Mohr et al., 2003; Reilly, 2003; Stølen et al., 2005).

The analysis of match effort shows the significance of players' motor preparation in contemporary football, which has direct influence on the players' technical and tactical abilities needed.

The work aims at characterizing training loads which are present during a championship match among young footballers, with special regard to answering the following questions:

1. What distance is covered by young footballers during a championship game, and what are the dynamics of the game in particular tactical formations during the first and the second half of the game?

2. What distance is covered by players until they reach the arbitrarily established speed threshold of $3.5 \mathrm{~m} / \mathrm{s}$ and after exceeding this speed?

3. How many sprints are there during a championship match and what is the maximum speed of young footballers?

\section{Methods}

The study was conducted on 10 young footballers of "Warta" Poznań Football Club, during a championship match with team "Aluminium" Konin. The match duration was 51 minutes and the game took place on a $100 \times 68 \mathrm{~m}$ football field. The average age of the participants was $13.5 \pm 0.4$ years and their average training experience was 4 years. The average body height of the players was $162.32 \pm 7.73 \mathrm{~cm}$ and the average body mass was $51.12 \pm 7.72 \mathrm{~kg}$. The goalkeeper did not participate in the research.

To analyze the selected motor performances of the players during the match, Erdman's (2000) kinematic method was used. The procedure was to record the course of the game, using a wide-anglelens camcorder. The obtained information was transferred into quantitative data by means of Kuzora's and Erdman's method (1998), using the program BANAL, which enabled us to mark the player's path or course of the selected moves (e.g., distance covered in meters-walking, trotting, running, sprinting), during the chosen parts of the game, as well as the whole game.

On the basis of the author's own research, as well as comparing the elements of a footballers' motion (from the perspective of physical exercise physiology of aerobic and anaerobic effort), the average speed of a young footballer was established to be $3.5 \mathrm{~m} / \mathrm{s}$ for AT (anaerobic threshold). The sprint speed was established to be $V \geq 5 \mathrm{~m} / \mathrm{s}$. This value is a result of the former pilot research. The analysis of the motor performances was conducted during the first and second half of the game. The results are shown as arithmetic means and standard deviation. To compare the values, Student's t-test for linked samples was applied. The significance level was $p \leq 0.05$.

\section{Results}

The study showed that the total distance covered during the 51-minute championship game by the young football players of "Warta" Poznań Football Club averaged 4,252 metres. The average values of the distance covered during the first and the second half of the match were similar $(2,106 \pm 214$ and 2,146 \pm 231 meters, respectively), which were not statistically significant - the difference between the halves was only 40 metres. The analysis of the individual results achieved shows that the longest distance during the game was covered by the left wing midfielder $(4,661 \mathrm{~m})$. A graphic representation of the differences between the distances covered during the first and second half of the match is shown in Figure 1.

The analysis of the distance covered by the examined footballers with regard to the different tactical formations showed that the longest, statistically significant distance at $\mathrm{p} \leq 0.05$ was covered by the midfielders $(4,486 \mathrm{~m})$, followed by the forwards $(4,152 \mathrm{~m})$. The defenders proved to have covered the 


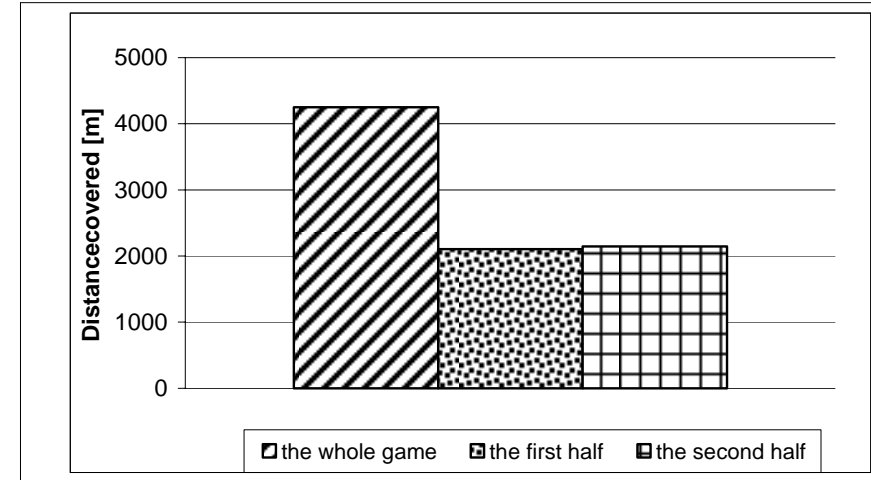

Fig. 1

Characteristics of the distance covered $[\mathrm{m}]$ by the examined footballers during the match

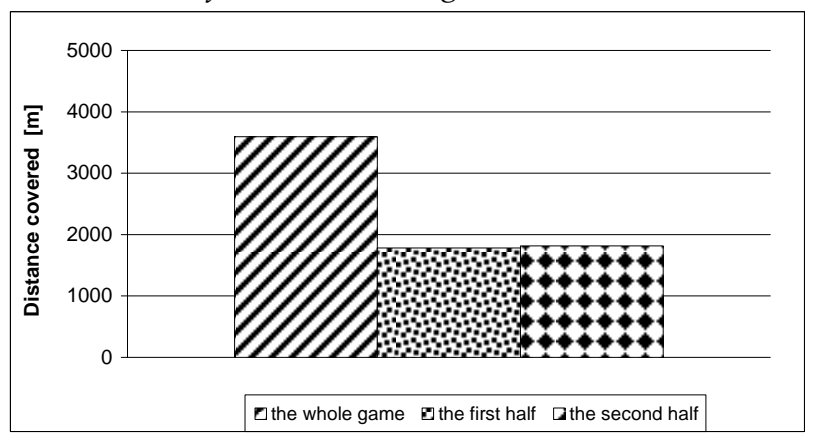

Fig. 3

Characteristics of the distance covered $[\mathrm{m}]$ by the examined footballers during the match

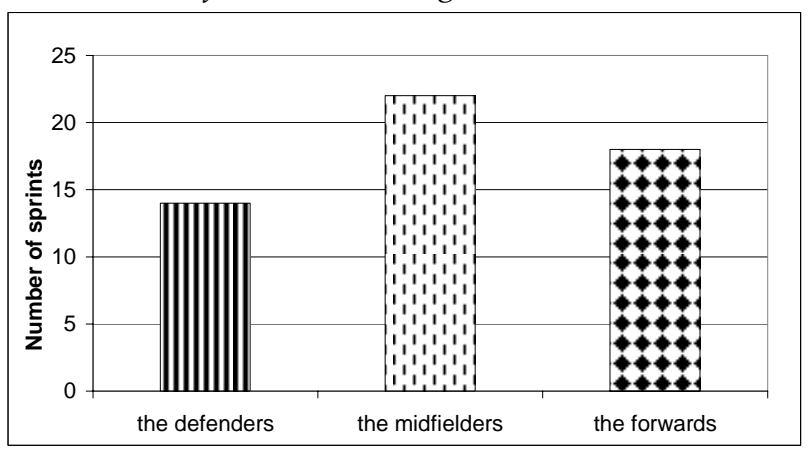

Fig. 5

Characteristics of the distance covered $[\mathrm{m}]$ by the examined footballers during the match

shortest distance of 4,068 metres. The obtained results are indicative of statistically significant differences seen between midfielders and defenders, as well as between forwards and defenders. Figure 2 shows the differences in the distance covered between these formations.

Characterizing the objective values of footballers' motion elements, from the perspective of physical exercise physiology of aerobic and anaerobic effort, the average speed of a young footballer was estab-

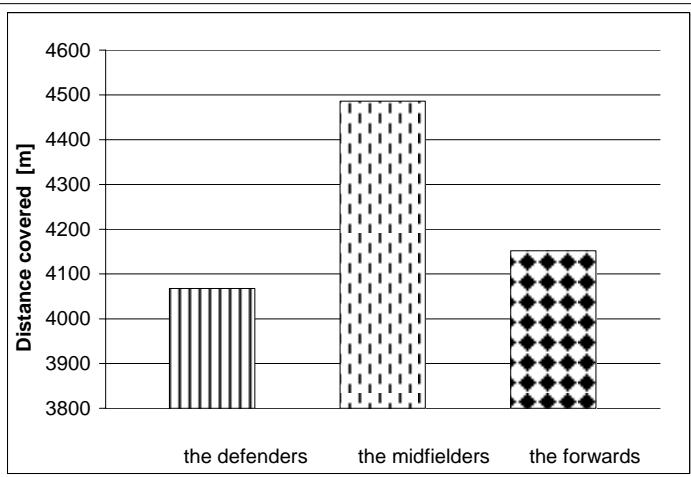

Fig. 2

Characteristics of the distance covered $[m]$ by the particular tactical formations

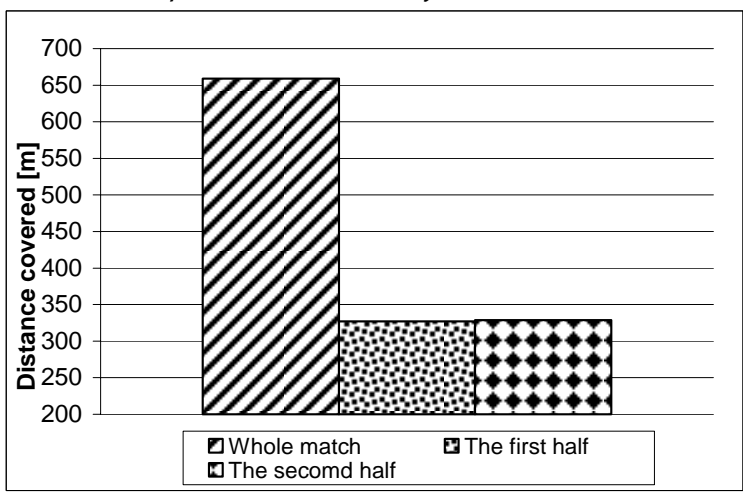

Fig. 4

Characteristics of the distance covered $[m]$ by the particular tactical formations

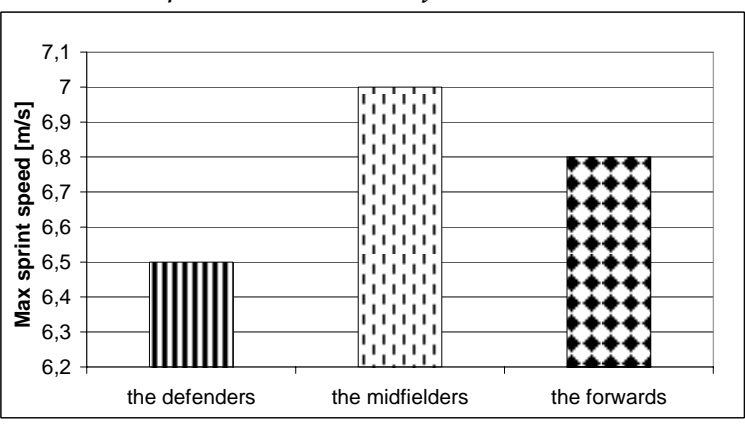

Fig. 6

Characteristics of the distance covered $[m]$ by the particular tactical formations

lished to be $3.5 \mathrm{~m} / \mathrm{s}$ and more for AT. (Kollath et al., 1996; Jastrzębski, 2004).

The analysis of the distance covered by footballers with the established speed below AT showed that it was 3,596 \pm 207 metres (Figure 3). During the first half of the game, the players covered on average $1,781 \pm 112$ metres, which was similar to the value achieved during the second half $(1,815 \pm 107 \mathrm{~m})$. The total distance covered by the players until reaching the threshold running speed of $3.5 \mathrm{~m} / \mathrm{s}$ makes up 
$84.57 \%$ of the total distance covered during the game.

A thorough examination showed that the players of the "Warta" Poznan team covered 656 metres with the speed above $3.5 \mathrm{~m} / \mathrm{s}$ (individual differences varied from 575 to $722 \mathrm{~m}$ ). The distance covered by the footballers during both halves of the game was similar, with a difference of only 2 meters between the halves. The right wing offensive midfielder covered the longest distance $(722 \mathrm{~m})$, with the established speed above AT (Figure 4).

Scrutinizing the number of sprints, it was found that one player covers 18 of them on average throughout the game. The highest individual value noted was achieved by the right-wing forward (24 sprints). With regard to the tactical formations, the midfielders proved the best (22 sprints on average), followed by the forwards (18 sprints). The lowest number of sprints was noted among the defenders (14 sprints) (Figure 5)

Figure 6 shows that the midfielders reached the highest speed of $7.0 \mathrm{~m} / \mathrm{s}$ on average. The forwards reached an average maximum speed of $6.8 \mathrm{~m} / \mathrm{s}$, and the defenders were the slowest players, with an average maximum speed of $6.5 \mathrm{~m} / \mathrm{s}$.

\section{Discussion}

One of the most important elements determining level of a contemporary footballer is motor preparation, which has a significant influence on their technical and tactical abilities used during a game. Even football players of high technical abilities make mistakes when inadequately prepared physically Thus, the structure of training loads in football must arise from the specificity of this game. That is why the characteristic of footballers' motor performances determine the scope of physical loads that are present during the game, as well as the character of the game effort. From a training point of view, the information about the distance covered by footballers during a championship game is of great importance for the practice of sport. Such information should have a significant impact on planning the particular workloads in a year training cycle.

The study undertaken allowed us to determine the amount of work that the players perform on the basis of the distance covered during a $2 \times 25 \mathrm{~min}$ championship match.

The obtained results indicate that the footballers cover the distance of 4,252 meters on average during a game (Figure 1). Training adaptation allows a player to adjust their abilities to real game situations, depending on opponents' demands or tactical guidelines of the team. During the first half of a game, teams attempt to learn each other's capabilities and possibilities, as well as use (among other variables) their technical and tactical preparation; they try to force their own optimal and effective style of play. This translates directly into the distance covered by the players, which is typically less in the first half of the game when compared to the second half. The difference in distance covered between the two halves was only 40 meters, which was statistically insignificant.

The study also aimed at finding field positions which determine the highest motor activity during a game. The kinematic analysis of the game showed that the longest distance was covered by the midfielders - 4,486 meters on average. Significantly lesser workload was performed by the strikers and the defenders who covered, respectively, 4,152 and 4,068 meters (Figure 2). The obtained results resemble those of Andrzejewski (2006).

It has been observed that lactate threshold is present among young football players when the speed is $3.5 \mathrm{~m} / \mathrm{s}$. This study demonstrated that the workload of the examined players below the AT speed of 3.5 $\mathrm{m} / \mathrm{s}$ was 3,596 meters (Figure 3), which makes up $84.57 \%$ of the total distance covered in an entire game. Aerobic capacity a player represents is determined by workload that is needed to achieve the threshold running speed. It has to be stressed that high aerobic capacity allows a player to achieve and sustain greater intensity for a longer period of each game. A high aerobic-capacity player possesses better fatigue tolerance and body recuperation. A shorter period of body recuperation after high-intensity effort allows a player to participate in subsequent matches, with maximum intensity (Chmura, 2001).

After exceeding the threshold of running intensity, lactic acid concentration grows dynamically in a player's body. The amount of workload above the anaerobic threshold (that is, the distance covered with the speed above $3.5 \mathrm{~m} / \mathrm{s}$ ) is indicative of the level of fatigue tolerance present during a game, as well as anaerobic capacity level of the players. This study conducted during match conditions showed that the distance covered with a speed above $3.5 \mathrm{~m} / \mathrm{s}$ was 656 meters, which makes up approximately 15.4 $\%$ of the total workload of young football players (Figure 4). These results point to the enduring char- 
acter of football, which indicate the importance of shaping and sustaining players' aerobic capacity during the training process.

This study is also an attempt to determine kinematic elements of the game regarding speed. Analyzing the number of sprint occurrences during the championship match, it was found that, on average, a player performs 18 sprints per game. Scrutinizing the tactical formations proved that the midfielders are the fastest players (averaging 22 sprints per game- 8 more than the defenders) (Figure 5). This has also been confirmed by the achieved values of average maximum speed of the players during the game (Figure 6). The results are similar to those obtained by Dargiewicz et al. (2004) and Andrzejewski et al. (2006).

Summing up, our study concurs with literature reviews, stating that physical loads among footballers during a match are essential to the process of individual training regimens. This allows for successfully planning and registering the applied loads, which is an inherent element of the contemporary training process. Knowing the profile and character of match efforts, that is, competition loads, makes it possible to implement the following rule: "training reflects game".

\section{References}

Andrzejewski M., Chmura J., Dargiewicz R., Charakterystyka wybranych czynności ruchowych młodych piłkarzy nożnych w czasie meczu mistrzowskiego. Monografia AWF we Wrocławiu, 7/2006: 133-149

Andrzejewski M., Wpływ indywidualizacji treningu na reakcje fizjologiczno-biochemiczne, psychomotoryczne i zdolności szybkościowe u młodych piłkarzy nożnych w półrocznym makrocyklu szkoleniowym. Dysertacja doktorska 2006

Bangsbo J, Norregaard L, Thorso F. Activity profile of competition soccer. Can J Sport Sci, 1991. 16 (2): $110-6$

Bangsbo J. The physiology of soccer: with special reference to intense intermittent exercise. Acta Physiol Scand, 1994. 151 Suppl: 619: 1-155

Bangsbo J., Sprawność fizyczna piłkarza. Nowe podstawy naukowe. Biblioteka Trenera, 1999. COS Warszawa

Castagna C, D'Ottavio S, Abt G. Activity profile of young the good of the game. Soccer players during actual match play. J Strength Cond Res, 2003. 17 (4): 775-80

Chmura J., Indywidualizacja obciążeń w treningu szybkościowym piłkarzy nożnych. Współczesna piłka nożna teoria i praktyka, AWF Gorzów 2001.: 7-24

Chmura J., Fornalik W., Piechniczek A., Szyngiera W., Wieczorek R. Charakterystyka wybranych czynności ruchowych piłkarzy nożnych i reakcji metabolicznych w czasie meczu mistrzowskiego. Monografia 4/2003: 714

Chmura J., Dargiewicz R., Andrzejewski M., Zdolności wytrzymałościowe i szybkościowe graczy w meczu eliminacyjnym do Ligi Mistrzów w piłce nożnej. Monografia AWF we Wrocławiu 5/2004: 77-87

Dargiewicz R., Chmura J., Andrzejewski M., Badania wielkości kinematycznych poruszania się formacji taktycznych w piłce nożnej młodzików na przykładzie analizy meczu Lech Poznań-1920 Mosina. Acta of Bioengineering and Biomechanics, 2004. 6 Suppl. 1: 255-259

Erdmann W.S. Rejestracja i analiza ruchu zawodników w zespołowych grach sportowych. Sport Wyczynowy, 2000. 9-10: 65-88

Harley RA, Tozer K, Doust J. An analysis of movement patterns and physiological strain in relation to optimal positioning of Association Football referees. In: Spinks W, Reilly T, Murphy A, editors. Science and football IV. London: Routledge, 2002:137-43

Helgerud J., Engen LC., Wisløff U., Aerobic endurance training improves soccer performance. Med Sci Sports Exerc, 2001. 33 (11): 1925-31

Jastrzębski Z. Zakres obciążeń treningowych i ich wpływ na dynamikę rozwoju sportowca uprawiającego piłkę nożną i piłkę ręczną. AWFiS Gdańsk 2004 
Kollath E., Krabbe B. (1996): Kinetic analysis of short sprints of soccer players. Sportonomics, 1996. 2: 55-58

Kuzora P., Erdmann W.S., Program komputerowy badania gier zespołowych. Materiały Ogólnopolskiej Konferencji, Gdańsk, 5-6 czerwca 1998. Red Erdmann W.S., Centrum Badań Lokomocji AWF-AM, Gdańsk: 163-168

Krustrup P., Mohr M., Ellingsgaard H., Physical demands during an elite female soccer game: importance of training status. Med Sci Sports Exerc, 2005. 37: 1242-1248

Mohr M, Krustrup P, Bangsbo J. Match performance of high-standard soccer players with special reference of fatigue. J Sports Sci, 2003. 21 (7): 519-28

Ohashi J, Miyagi O, Nagahama $\mathrm{H}$, et al. Application of an analysis system evaluating intermittent activity during a soccer match. In: Spinks W, Reilly T, Murphy A, editors. Science and football IV. London: Routledge, 2002: 133136

Reilly T. Motion analysis and physiological demands. In: Reilly T, Williams AM, editors. Science and soccer. London: E \& FN Spon, 2003: 59-72

Reilly T., The science of training - soccer. A scientific approach to developing strength, speed and endurance. Routledge 2007; Taylor \& Francis Group. London and New York

Rienzi E, Drust B, Reilly T, et al. Investigation of anthropometric and work-rate profiles of elite South American international players. J Sports Med Phys Fitness, 2000. 40 (2): 162-169

Spencer M, Bishop D, Dawson B, et al. Physiological and metabolic responses of repeated-sprint activities. Sports Med, 2005. 35(12): 1025-1044

Stølen T., Chamari K., Castagna C., Physiology of soccer: an update. Sports Med, 2005. 35(6): 501-536

Strudwick T, Reilly T. Work-rate profiles of elite Premier League football players. Insight FA Coaches Assoc J, 2001. 4 (2): 28-29

Wisløff U, Castagna C, Helgerud J, et al. Maximal squat strength is strongly correlated to sprint performance in elite soccer players. Brit J Sports Med, 2004. 38 (3): 285-8

Valquer W, Barros TL, Sant'anna M. High intensity motion pattern analyses of Brazilian elite soccer players. In: Tavares F, editor. IV World Congress of Notational Analysis of Sport; 1998 Sep 23-27; Porto. Porto: FCDEF-UP, 1998: 80.

\section{Corresponding author}

\section{Dr Marcin Andrzejewski}

Faculty of Methodology and Recreation

University School of Physical Education, Poznan,

ul. Rybaki 19 61-884 Poznan, Poland

Phone (061) 8355326

Fax. (061) 8517384

E-mail: andrzejewski@awf.poznan.pl 